\title{
Veiling the Superhero: A Comparative Analysis of Dust and Qahera
}

\author{
Safiyya Hosein ${ }^{1 *}$
}

Published: April 11, 2020

\begin{abstract}
This article conducts a comparative analysis of the Egyptian webcomic superhero, Qahera with Marvel's XMen superhero, Dust by analysing the symbolic meaning of the veil in their storylines. By applying existing research from both comic scholars and postcolonial feminist researchers, this article illustrates how the veil can be used as a tool to perpetuate colonial prejudices as we see with Dust - or subvert them in the case of Qahera. Through both humour and political allegory, Qahera the Superhero has created a sensitive narrative for the veiled superheroine which speaks to the everyday life of a veiled Muslim woman in Egypt.
\end{abstract}

Keywords: Qahera the superhero, webcomics, veiling, Sooraya Qadir, Dust, Muslim superheroes, colonial feminism

\section{INTRODUCTION}

In recent years, webcomics have enjoyed a surge in popularity with Muslim women creators such as Huda Fahmy and Sanya Anwar making comics that destabilise orientalist constructions of Muslim women through humour and insight. For many years, the depiction of Muslim women in comics was dependent on industry gatekeepers such as Marvel and DC who often characterised them as either oppressed or - in the case of belly dancers - hypersexualised. In this article, I will compare two veiled Muslim superheroes - Marvel's X-Men superhero, Dust and the Egyptian webcomic superhero, Qahera. The purpose is to illustrate how the medium of webcomics is a powerful tool that makes Muslim women from the Global South active agents in shaping their own narratives. By illustrating how gatekeepers construct veiled Muslim women, this comparison will reveal how the webcomic Qabera the Superbero provides a counter-narrative to popular conceptions of veiled Muslim women as exoticised and oppressed. As a result, webcomics are significant in destabilising orientalist narratives about Muslim women by including their voices into media discourses and are thus a powerful social justice tool of representation.

\section{THEORISING THE MUSLIM SUPERHERO}

Muslim characters have been a part of comics for decades but have only taken on deeper significance in the post 9/11 era with Muslim superheroes such as Ms. Marvel's Kamala Khan and the Green Lantern's Simon Baz. While representation has come a long way for the depiction of Muslims in comic books, there is still room for improvement. Before the surge in popularity of Muslim superheroes, Jack Shaheen brought attention to the depiction of Muslims in American comic books in the 1990s. In his article 'Arab images in American comic books', Shaheen discusses a typology of Arab Muslim representation that mostly prioritises Muslim and Arab masculine constructions. However, his analysis of Arab gender roles included the depiction of Arab Muslim women whom he described as being 'doomed to one of two illustrations, either a scantily-clad or salivated-upon belly dancer, or a faceless housewife, whose thick-set form is bundled up in dark robes' (Shaheen, 1994: 129). The latter construction of the faceless housewife is undoubtedly descriptive of the stereotype of the veiled Muslim woman. Shaheen described the faceless housewife as inconsequential to the plot whose main purpose is served being 'part of the setting', never to be spoken to or to speak, and thus being 'devoid of personality' (Shaheen, 1994: 129). Therefore, veiled Muslim women in a pre-9/11 context in North American comic books continues to perpetuate the stereotypical construction of being oppressed and lacked any real significance in the narrative.

${ }^{1} \mathrm{PhD}$ candidate in the joint program in Communication and Culture at Ryerson University and York University in Toronto, CANADA

*Corresponding Author: safiyya.hosein@ryerson.ca 
However, after 9/11, Muslim women seemed to take on new significance for the American comic book publishers Marvel and DC, who sought to capitalise on the wider media sensationalism of Muslims by including them in their superhero lexicon. The earliest of this inclusion was the X-Men Sooraya Qadir, codenamed Dust. As a niqabi superhero, who flayed her opponents alive with lethal sand particles, the faceless housewife was reinvented with a personality and an orientalist superpower, making her far more relevant to the genre of comics than before. Furthermore, whenever she transformed from being fully veiled and robed in her human form into a naked sand form when she used her superpower, her characterisation seemed to merge with Shaheen's belly dancer type. Julie Davis and Robert Westerfelhaus analysed Dust's representation somewhat imperfectly in their short essay 'Finding a place for a Muslimah heroine in the Post-9/11 Marvel Universe: New X-Men's Dust', which paid much attention to the superheroine from a gendered perspective but failed to engage with any of the substantial issues regarding the representation of her race/ethnicity. After pointing out how Dust's religion has been used more as a tool for sensationalism, it didn't engage with the character's orientalist construction. For example, the authors justify her demeaning superhero name as a connection to the 'arid sands of the Arabian and Saharan deserts', when both her name and the superpower itself relied too much on a stereotypical perception of the Middle East as an uncivilised desert region (Davis and Westerfelhaus, 2013: 804). When it came to engaging with her deeply sexualised imagery, the article merely dismissed her naked sand form as reminiscent of pornography, when it was in fact more reminiscent of eighteenth and nineteenth century harem paintings. The article concluded that she was marginalised in comics simply because she was a woman as opposed to being a woman of colour, the authors being seemingly unaware of the fact that non-white female superheroes have historically been given much less of a symbolic presence in comics than their white counterparts.

However, it is worth pointing out that the veiled Muslim woman has been sensitively constructed most notably (perhaps unsurprisingly) in Middle Eastern superhero comics. The 99 is a Kuwaiti comic that was inspired by the powerful characters of DC and Marvel comics. Its characters are young men and women gifted with superpowers that personify the '99 attributes of God'1 (an Islamic scriptural concept) and are in a perpetual battle with the comic's chief villain named Rughal. By blending Islamic mythology with actual historical knowledge of the Mongols, The 99 series has gained a cult-like following in North America. Shirin Edwin's article, 'Islam's Trojan horse: Battling perceptions of Muslim women in The 99', analysed the Muslim female superheroes from the series, describing the text as a 'polemic on Islam and Islamic feminism, in particular' (Edwin, 2012: 171). Edwin's article looked at multiple female characters - some veiled, others non-religious, and from a variety of backgrounds. Her essay primarily focused on their body language, dress code and personalities. One of her most interesting analyses was of the veiled superhero Batina, whose power is the ability to hide and move undetected through surveillance. The character's natural inclination is to stay hidden but because of her 'Noor stone'2 she is compelled to became visible. Edwin surmises that:

Significantly, Batina's powers, and her own personal struggles, powerfully reflect the choice of Muslim women behind the veil who nevertheless make consistent, if unacknowledged, contributions to society. (Edwin, 2012: 182)

The implication that a Muslim female superhero would be empowered by her faith is predictable here since the series originated from the religious and culturally conservative Middle Eastern Gulf state, Kuwait. But what was notable about Edwin's observation, was her connection between the character and her veil. It can be argued that Batina's veil was allegorical to her shy personality, which often motivated her to stay hidden. Given that her superpower was based on faith (the Noor stone is an allusion to Islamic mythology), her storyline thus rounds her characterisation off appropriately with that the Noor stone is symbolically compelling her to be brave and thus be seen.

No article on the Muslim superhero would be complete without a discussion of the rebooted Ms. Marvel, the Pakistani-American teen Kamala Khan, who debuted to much fanfare in October 2014 and remains one of Marvel's most popular superheroes - a heartening fact when one considers that the character is far more sensitively told than the orientalised Dust (Diamond, 2014). Arguably, the figure of Kamala Khan is a giant step forward from the faceless housewife and the belly dancer construction of traditional Muslim representations in comics. However, despite her more sensitive construction, scholars have discussed some problematic aspects of the Ms. Marvel comic series. In 'Comics as public pedagogy: Reading Muslim masculinities through Muslim femininities in Ms. Marvel', Shenila S. Khoja-Moolji and Alyssa D. Niccolini pointed to one panel in Issue \#1 that depicted the new Captain Marvel, Carol Danvers, passing on the 'Ms. Marvel' mantel to Kamala in the form of a 'celestial' being, which they concluded can be interpreted as a subtle reinforcement of the white saviour complex (Khoja-Moolji and Niccolini,

\footnotetext{
${ }^{1}$ Usually referred to as 'The 99 Names of Allah' but Allah is the Arabic word for 'God' and is used by Muslims and Arabicspeaking Christians.

2 The superheroes in The 99 receive their superpowers from a fictional artifact called the 'Noor stone'.
} 
2015: 29). The visual panel in question depicts Captain America, Iron Man, and Carol Danvers, descending from above in a cloud of smoke with their hands in the air (Iron Man's is folded to his chest) in front of a mesmerised Kamala, which tends to confirm Khoja-Moolji's and Niccolini's analysis. This same visual panel was further analysed in Sarah Gibbons's article, 'I don't exactly have quiet, pretty powers': Flexibility and alterity in Ms. Marvel, for its celestial connotations, which aptly connects it to the kind of Christian iconography found in Raphael's painting The Transfiguration (1520). While both articles do speak of the mostly positive representation of Kamala, their point about the white saviour complex depicted in the panel, as well as Khoja-Moolji's and Niccolini's observations about 'normality' in the comic being 'invisibly marked by Christianity' provides salient contributions (Gibbons, 2017: 28). I would argue that an improvement on orientalist representations in superhero comics does not equate to an unproblematic Muslim representation. Since the debut of Dust, in which white saviourism was more overt, the subtle use of imagery that depicts white superheroes as saviours appears to have become a worrying trend in Muslim superhero representation.

\section{THE VEILED AMERICAN SUPERHERO: AN ANALYSIS OF DUST}

At the beginning of the USA War on Terror, Marvel Comics introduced Dust in December 2002 in the New $X-M e n$ series, Issue \#133. Dressed in a traditional abaya (a Middle Eastern style of dress), Dust is predominantly portrayed as veiled. Despite this veiled representation, she is not an asexual character, devoid of any desirable gaze. On the contrary, her abaya is form-fitting to imply ample cleavage and curves beneath her garment, and her eyes are well-defined as the only facial feature that the audience is afforded (in Middle Eastern cultures where the female is veiled, or scarfed, eyes can carry a significant sexual power). A key element of her character's costume is wearing the niqab as a protection from prurient gaze. When a superhero colleague searches for her in a post-battle scene in a later issue, she is reluctant to go back into human-form because she 'has no clothes' and therefore cannot make it back to the X-Men school dormitory fully veiled. In yet another scene, she defends her choice to eat alone, stating it is because 'it requires me to take off my hood (Davis and Westerfelhaus, 2013: 804). Her portrayal as a Muslim superheroine does not appear to be so much a benevolent move of diverse inclusion bestowed by Marvel, rather the figure is a trope that continues to reinforce blatant orientalist stereotypes that produces the age-old clash-ofcivilisations binary.

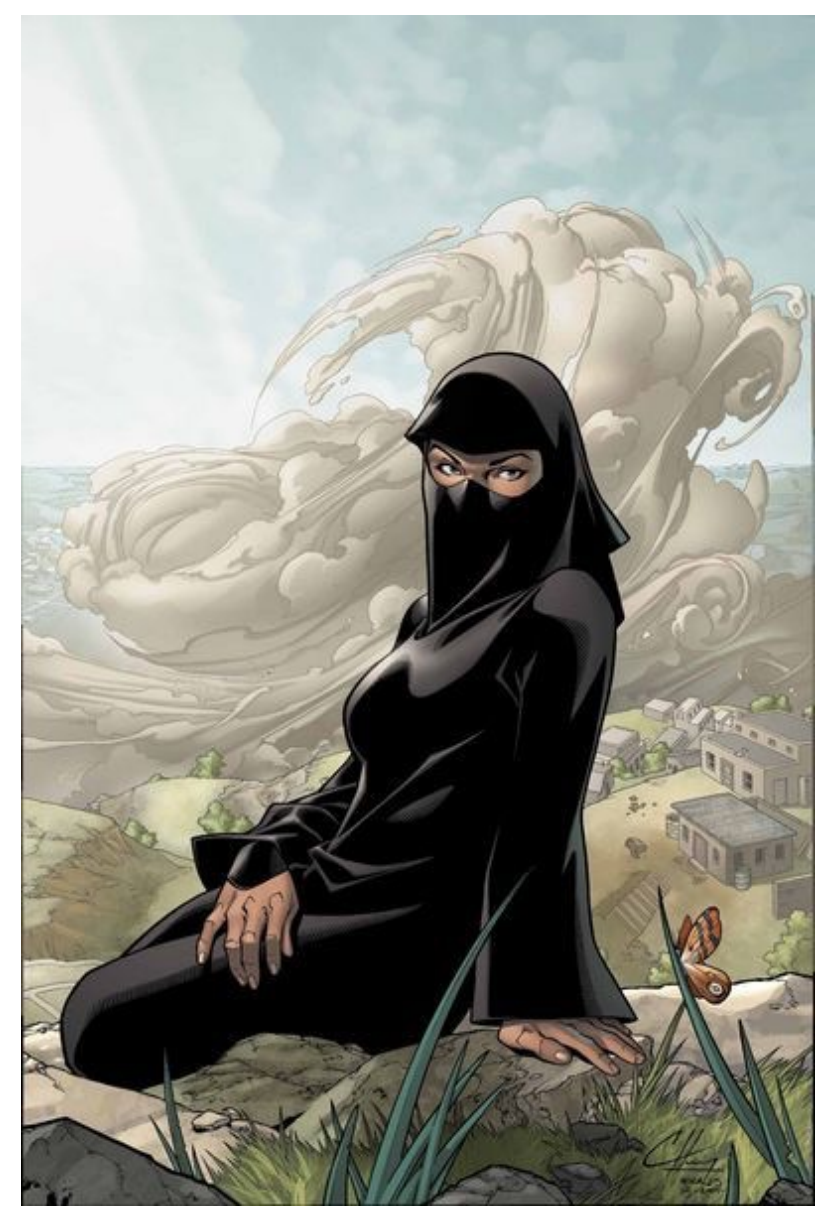

Figure 1. Henry, C. (2005). Dust on the cover of New X-Men: Hellions Vol.1, August 2005. C C. Henry. 
It is important to consider the context of production and the possible intention in creating Muslim superheroes. The reader may wonder why superhero comics are so eager to make a Muslim character a 'good' one (and more so a superhero fighting in the name of freedom) in an age of western tension with the Islamic world? One possibility could be best explained through Gayatri Spivak's work on the 'domesticated Other' and the 'imperialist self. In 'Three women's texts and a critique of imperialism', Spivak examines the works of authors Charlotte Brontë, Jean Rhys, and Mary Shelley to deconstruct the imperialist undertones in their feminist works. She states:

No perspective critical of imperialism can turn the Other into a self, because the project of imperialism has always already historically refracted what might have been the absolutely Other into a domesticated Other that consolidates the imperialist self. (Spivak, 1985: 253)

Dust can best be described as an epitome of Spivak's 'domesticated Other' consolidated for the 'imperialist self'. Spivak referenced this binary when exploring imperialism and feminism in her analysis of the works of the three White female authors she examined. Throughout her essay, she expresses wariness of the limitation of feminist individualism when analysing western literature that alludes to the Third world and its diasporas. In many ways, a veiled Muslim superheroine like Dust represents the same type of binary as the 'domesticated Other' on one end, and the 'imperialist self' on the other end. In his book Understanding Comics, Scott McCloud details the power of drawing in comics in which he argues that the purpose of cartooning lies in its 'amplification through simplification' format. In his chapter, 'The vocabulary of comics' he refers to icons before discussing images and states that 'by stripping down an image to its essential 'meaning', an artist can amplify that meaning in a way that realistic art can't' (McCloud, 1994: 30). If we combine both McCloud's and Spivak's observations, then the 'domesticated Other' is amplified as Islam through its orientalist, veiled character and the 'imperialist self' is the western audience that the character is created for.

The impulse to domesticate the Oriental subject has far-reaching, arguably racist and gendered implications. In her article, 'Do Muslim women need saving? Anthropological reflections on cultural representations and its others', the anthropologist and scholar Lila Abu-Lughod, mentions a $1^{\text {th }}$ century conference proceedings book by Christian missionary women entitled A Cry of Need from the Lands of Darkness Interpreted by Those who Heard it. Citing the need to save their veiled counterparts "who will never cry for themselves, for they are down under the yoke of oppression', Abu-Lughod questions exactly why it is necessary to save these women, and for what reason? (AbuLughod, 2002: 789) The clear implication is that we are saving them from Muslim men - an archetype of orientalist masculinity that has too often endured racist stereotypes as savage, oversexed and uncivilised. It is thus no coincidence that our first introduction to an ostensibly powerful Muslim female superhero like Dust is presented as incapacitated in her first scene while she is rescued by the white hyper-masculine ex-soldier superhero Wolverine, who saves her from none other than these uncivilised Brown men who dare to unveil her and thus strip her of her modesty. Ironically, these Brown men are members of the Taliban, a group of religious fanatics who have notoriously mandated veiling in territories in Afghanistan that they control, a fact completely ignored. After Issue \#133 opens with Wolverine valiantly fighting off several Taliban members somewhere in Afghanistan, the reader is privy to him walking into a tent only to find an unconscious Dust in the arms of a French thief Fantomex, who is about to sell her into the mutant ${ }^{3}$ slave trade. After remarking on the deplorable treatment of women in the Taliban-era Afghanistan, Wolverine expresses incredulity that Fantomex would exploit their vulnerability (Morrison, Van Sciver and Rapmund, 2002). The politics of the scene is ripe with meaning when one considers that around the same time that the comic was written, the French had rebuffed the USA in their recruitment of western allies to join them in the invasion of Iraq. Therefore, the opening scene seems to be a mouthpiece for the writer Grant Morrison's political views, and the text infers that the artist disapproved of the French government's choice during that time. The incapacitated Dust is first seen in the arms of Fantomex before the last panel shows her in the arms of Wolverine. Such an example of rescue by a white male from first the Taliban and then the Frenchman not only positions Wolverine as a white male saviour but lays the 'white man's burden' squarely on an American. And whilst Wolverine was born in Canada, his prior US Army service and his current home combines a form of American nationalism with white masculinity.

It is important to discuss the cover of Issue \#133 which was the issue that marked Dust's debut. Her veiled face appears on the front cover which is all black except for a slit of skin, revealing alarmed green eyes and dark eyebrows, reminiscent of the iconic 1980s National Geographic cover of a startled green-eyed Afghan girl (McCurry, 1985). In a disappointing turn, the issue that introduces her depicts her from the start as marginalised by placing her on the periphery of the main storyline where the primary focus is the rescue of Professor Xavier, which seems at odds with her feminine and coquettish eyes which make the cover. Most troublingly, she is devoid of any dialogue in this issue save for one Arabic word, toorab [dust], that she repeatedly utters in the ending, after being coaxed to come out of her sand-form by Jean Grey. The scene in question is troublesome when one considers the

\footnotetext{
${ }^{3}$ Mutants are superheroes in the X-Men series.
} 
fact that Dust we learn, is a mutant with particularly strong powers. While the X-Men regroup in their Mumbai headquarters, the red-headed American superheroine Jean Grey uses the mutant-location device cerebro ${ }^{4}$ to try to locate Dust who is described earlier on as simply a 'mutant refugee' (Morrison, van Sciver and Rapmund, 2002). While the X-Men gabber on in lively conversation, they notice the dust that is settling around a sleeping Wolverine. Jean Grey soon announces that the mutant is in the room but just not in human form and begins to talk to Sooraya, coaxing her into showing herself by reminding her that they were the ones who rescued her. This is shocking when one considers that earlier on Dust was powerful enough to flay thirteen Taliban members alive in her superpower form. The idea of a mutant that powerful being scared to appear in front of the others is a puzzling disempowerment. The scene also juxtaposes Dust with another female character - the brave, jeans-clad white American woman, Jean Grey, who is also positioned as a 'saviour' who seemingly conjures her up, thus reinforcing Spivak's observations of the domesticated Other.

Dust's transformation from sand to human form is the most telling in terms of her sexual objectification since there is a clear imprint of her undressed body in sand-form before we see her appear veiled as a human being, in a form-fitting abaya with a curvaceous silhouette and the same alarmed eyes. It is worth noting that the first image we see of her transformation in Issue \#133 was less sexualised and slightly morbid with her ribcage featured in one panel. However, later transformations became more overtly sexualised with her naked body more clearly illustrated in sand form. Dust, the implied radical that cannot eat in front of others because she must first remove 'her hood' and the defender of the niqab, becomes domesticated by the male gaze. Her lack of dialogue implies that she is there for us to watch, objectified, and her non-existent English-speaking abilities only serves to accentuate her exoticism. In 'Estranging the familiar: 'East' and 'west' in Satrapi's Persepolis', Nima Naghibi and Andrew O'Malley describe the veil in terms of a 'radical otherness':

As Gayatri Spivak has famously argued, the project of imperialism has historically been to transform the radically other into the domesticated other in a way that consolidates the (western) self. (Naghibi and O’Malley, 2005: 226)

In their argument, the veil is the icon that amplifies the character's construction and simplifies her as a representative of a foreign civilisation. Already marginalised as a secondary character, Dust is reduced to being a talking niqab. This comic symbol of 'radicalised otherness' requires domestification, her purpose is to render an idealised version of the radicalised Other that is domesticated by the western/American subject. She is nonthreatening and marginalised and the object of the male gaze.

The Islamic feminist Leila Ahmed has noted the hypocrisy of western colonisers who were obsessed with emancipating Muslim women while also opposing women's own emancipation campaigns in their home countries (Ahmed, 1993: 152). Having coined the term 'colonial feminism', Ahmed stated that during Lord Cromer's governorship in Egypt, he made de-veiling his mission while simultaneously opposing the Suffragist movement in his native country, Britain (Ahmed, 1993: 151). She points out that the Suffragist movement challenged Victorian norms and social mores - which Cromer defended. In her book Retbinking Orientalism: Women, travel and the Ottoman empire, Reina Lewis says of the harem:

There is no denying it - as a topic, the harem sold books... Publishers knew it, booksellers knew it, readers knew it and authors knew it. (Lewis, 2005: 12)

Lewis' argument speaks to the power of the veil in popular culture which is an artefact often conjured up in conjunction with the western image of the harem and repeated in mainstream comics. Because Dust is depicted as naked in her superpower form and only returns to her veiled self when she is human, she evokes the harem painting and its mystical sexuality. But in depictions outside the harem, Muslim women were often veiled. Harem paintings, veils and white saviours typically reinforce colonial prejudices which can be emboldened in the form of symbolic archetypes deployed in contemporary comments.

\section{THE VEILED EGYPTIAN SUPERHERO: AN ANALYSIS OF QAHERA}

In July 2013, a previously unknown Egyptian illustrator named Deena Mohammed created a witty comic on Tumblr meant to be a joke to her friends and poke fun at a misogynistic cleric in Egypt. The comic made a lighthearted point about misogyny on Egyptian TV, and became a sensation on Tumblr. It soon ballooned into a bigger project entitled Qahera the superhero and became a fan favourite online (Mohammed, 2013). The veiled superhero has a mission to fight misogyny at home while fighting Islamophobia abroad. The webcomic's cult-like following

${ }^{4}$ Cerebro is a fictional device that locates mutants in the X-Men series. It was invented by two of the series' most important characters, Professor Xavier and Magneto.

(C) 2020 by Author/s 
and clever social justice messages soon attracted attention in western media outlets such as the BBC, Foreign Policy, The Washington Post, and Vice. Qahera the superhero's playful style has helped make the comic an attraction, in its ironic and boldly honest take on being a Muslim woman.

The construction of the character is notably different to Dust. Qahera is also dressed in an abaya but vacillates between wearing a hijab and covering her face with a veil at other times. But she is never seen nude, and her looserfitting costume follows the Islamic requirements for modesty. By being a superhero that defends many different types of Egyptians, Qahera makes it clear that she is not bogged down by the constraints of patriarchal interpretations of religious scripture. In her comic On Basic Equality and Such, Qahera is seen saving Egyptian dogs, Copts, partying women, street thugs, and families much to the chagrin of a judgmental male bystander who chides her for 'not rescuing men' (Mohammed, 2019). Despite the character's admonishment, she continues to rescue people he disapproves of. In 'Beyond the veil: Graphic representation of Islamic women', Jackie Duncan does a comparative analysis of Qahera with Marjane Satrapi's Persepolis (2004) by analysing the use of the veil in both those texts. She acknowledges that the veil 'has long been stigmatised as a form of oppression' (Duncan, 2015: 1) and determines that representations of the veil in Qahera as well as the graphic novel Persepolis illustrate multidimensional complexity. She surmises that the veiled superhero in Qahera 'is imbued with superpowers to become a visible symbol of power under a veil' thus embracing her veil and using it as a source of power (Duncan, 2015: 2). She states that in Persepolis the main character 'uses her rebellious spirit to approach the issue' and consistently rebels against the suffocating limitations of an Islamist Iran (Duncan, 2015: 2). Thus 'the freedom to choose whether to practice veiling or not is what both texts are essentially referring to' (Duncan, 2015: 2). Duncan's essay concludes that:

Both interpretations offer an understanding for a more complex interpretation of the Islamic women through their perceptions of the veil. A complexity that is compounded by veiling being stamped as an inherent symbol of otherness. (Duncan, 2015: 3)

Duncan is not the only scholar to note the uniqueness of comics in deconstructing the veil, and orientalism/Islamophobia. Gillian Whitlock also discusses veiling when she analyses Persepolis in her chapter 'Autographics' in her book Soft weapons (2007). When examining the use of the veil in Satrapi's schoolyard playground, Whitlock remarks on its triviality to young Muslim girls when Satrapi and her peers use it as a toy to play skipping, rather seeing it as a 'piece of cloth, and its fetishization by adults can seem strange' (Whitlock, 2007: 190). This kind of critical intervention is novel for it treats the veil as an insignificant artefact of no real importance which is a perspective that is rarely ever communicated in popular culture. Similarly, Qahera seems to reduce this over-worked cultural symbol, as to her it is only useful in the superhero wardrobe. The costume does not wear the character but rather the other way around, unlike the case with Dust.

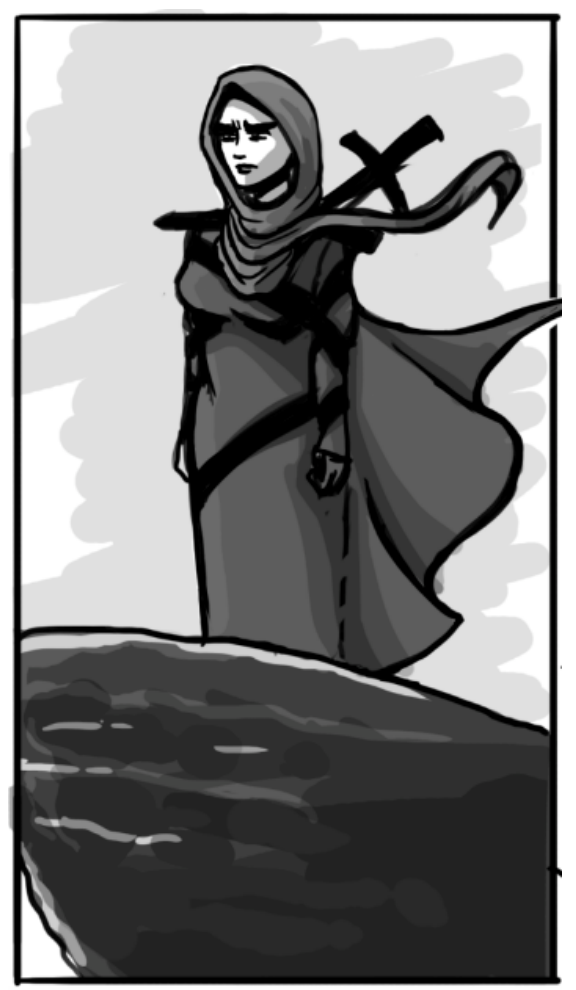

Figure 2. Mohammed, D. (2013). Qahera the Superhero, Egypt, Tumblr, June 30 th 2013. (C) D. Mohammed. 
Qahera is an allegory that synchronises the hybridity of text and images closely together. In 'Part 1: Brainstorm', the comic starts off with the veiled superheroine denoting 'misogynistic trash' with her supersonic ears before a comic panel cuts to a cleric telling a group of men that the best wife is an obedient wife (Mohammed, 2013). Soon after Qahera attacks the surprised cleric and hangs him on a clothesline with two laundry clips before telling him that he's right that 'housework is women's work absolutely' (Mohammed, 2013). As noted in 'Part 10: On basic equality and such', she pokes fun at an ignorant bystander who insults her incessantly. It ends with her saving someone who looks like him with him finally giving his nod of approval. The point of the comic is to make jest out of conservative Muslim masculinity. Qahera is often regarded as satirical for this reason.

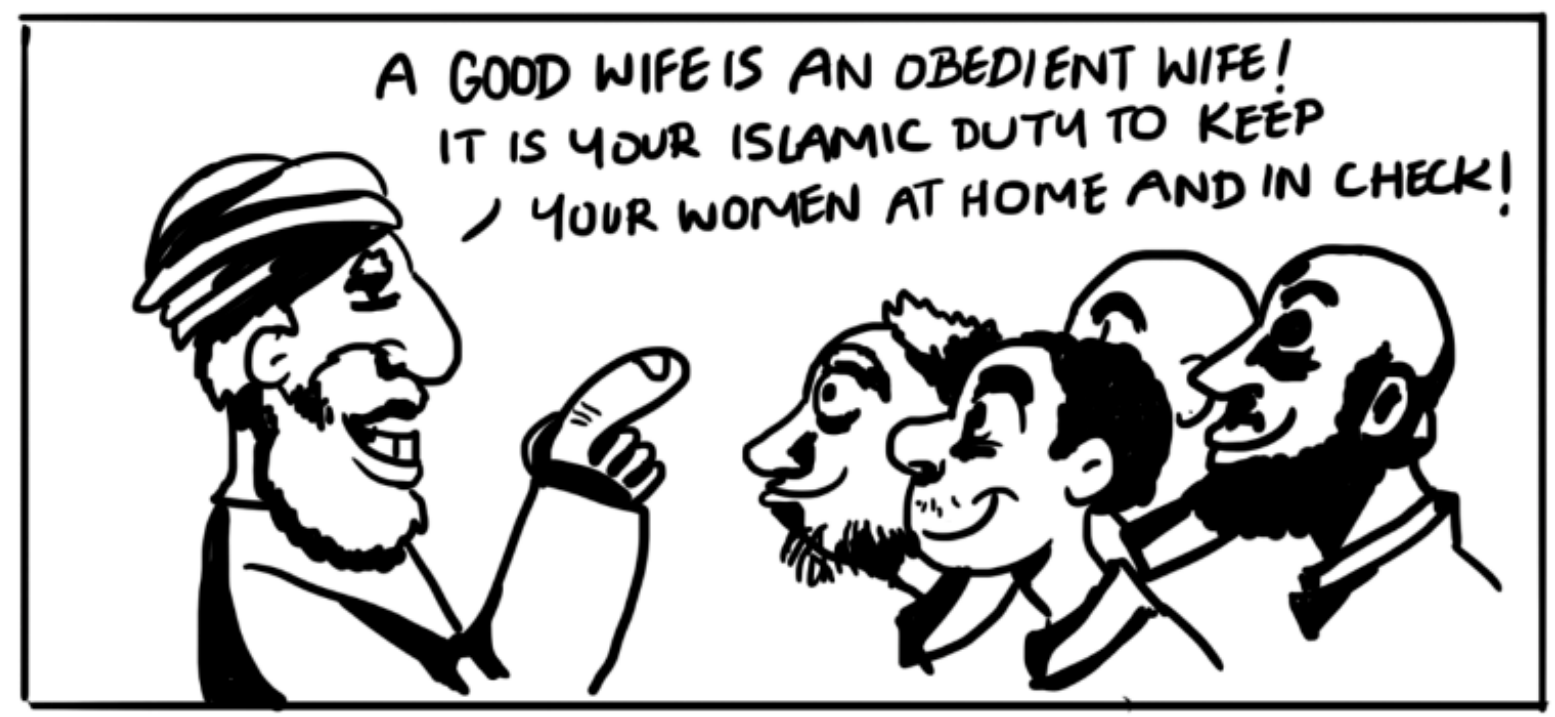

Figure 3. Mohammed, D. (2013). Qahera the Superhero, Egypt, Tumblr, June 30th 2013. C) D. Mohammed.

Qabera the Superhero is very much a polemic on inclusive feminism. The character openly assists marginalised members of society like refugees while standing up for Egyptian women during the Arab Spring protests in Tahrir Square, and she has tackled everything from classism to racism in her statements. One of the earlier comics on the European feminist group, FEMEN ${ }^{5}$ attracted criticism because of its purported violence which is surprising when one considers the fact that Qabera the superhero is a humorous superhero comic. The Qabera artist has discussed the criticisms in her interview with Disorient magazine (Kleer and Taxis, 2019) as well as another one where she went into even more detail (Aleya, 2018). When FEMEN protested in front of a Swedish mosque in June 2013, perhaps they and western audiences in general were not prepared for counter-narratives from Muslim artists to fight for women's rights. The comic illustrates an annoyed Qahera staring at her computer screen while FEMEN members protest bare-breasted in front of the Swedish mosque. During the protest, Qahera veils herself before she confronts them. After the FEMEN protestors make condescending remarks about needing to 'save' her, she uses her sash as a lasso to capture them, before she transports them to a far-off location to dangle them over a cliff stating, 'Hey so, feel free to rescue me anytime... the question is who's going to rescue you?' (Mohammed, 2013). According to the online news portal The Huffington Post, the real-life protest in Sweden only saw three FEMEN protestors who described themselves as 'sextremists' and were subsequently arrested for their protest (Bennett-Smith, 2013). In an interview with Disorient magazine online, Mohammed responded to some of the criticism of the FEMEN comic by stating that:

The problem is to define feminism through gender issues only, without taking anything else into account. You can't be a feminist if you are oppressing other women. You can't be a feminist if you are classist or racist. A lot of people in Egypt tend to disrespect feminism because they are very familiar with a very bourgeois type of feminism that is aligned with the state. People offend your intellect when you are expected to believe a feminism that claims to fight for women's rights but disrespects other human rights. (Kleer and Taxis, 2019)

In referring to FEMEN's Islamophobic views on veiling as a form of oppression the counter-argument by Islamic and/or Muslim feminists is posed of Muslim women's agency when it comes to choosing to veil.

${ }^{5}$ A European feminist group who refer to themselves as 'sextremists'. They include atheism in their ideology and protest topless. 


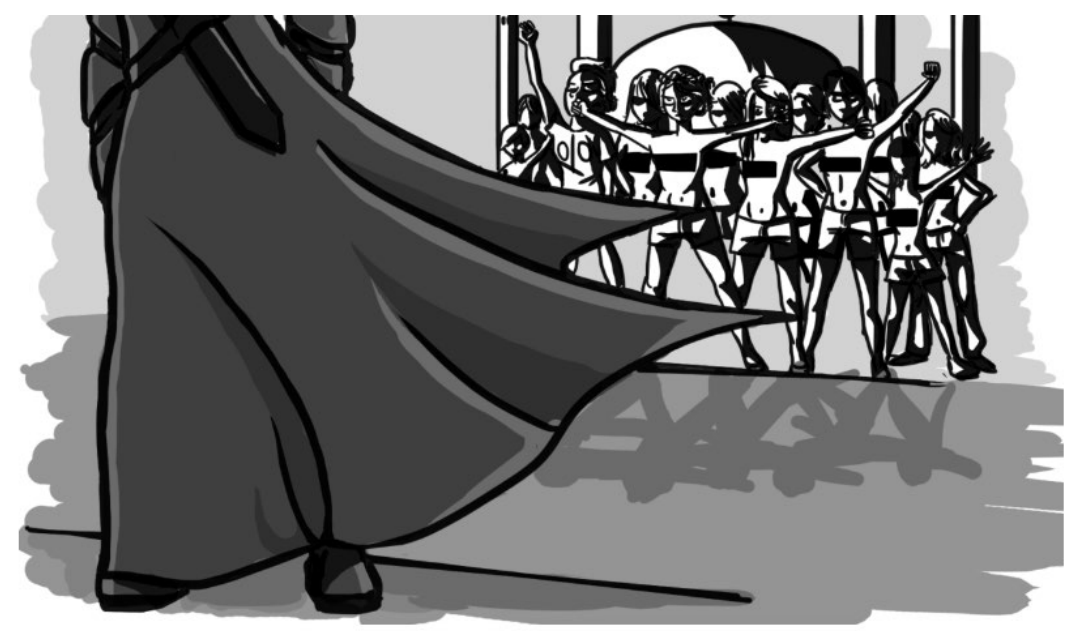

Figure 4. Mohammed, D. (2013). Qahera the Superhero, Egypt, Tumblr, July 20th, 2013. C D. Mohammed.

In the FEMEN comic the creator appears to draw a direct allusion to Wonder Woman, a feminist superhero who has also faced criticism for being too sexualised, as indicated in the UN's brief choice for Wonder Woman as an ambassador for the empowerment of women and girls for which they faced intense backlash for choosing an icon that was decidedly too sexualised. After protests and an online petition was launched, the decision to use her as an icon was rescinded (Ross, 2016). A hallmark weapon of Wonder Woman is her magic lasso, so when in the FEMEN comic Qahera uses her sash as a make-do lasso to capture the FEMEN protestors, this allusion appears deliberately intertextual. Another interpretation of Qahera's ad-hoc lasso can be to suggest a sense of solidarity with other iconic female superheroes and an attempt to indigenise the superheroine trope to an Egyptian Muslim audience. From this angle, the comic can be read as one that builds solidarity with feminist allies. (It is also quite possible that the comic was providing commentary on the policing of women's choices in dress as well.)

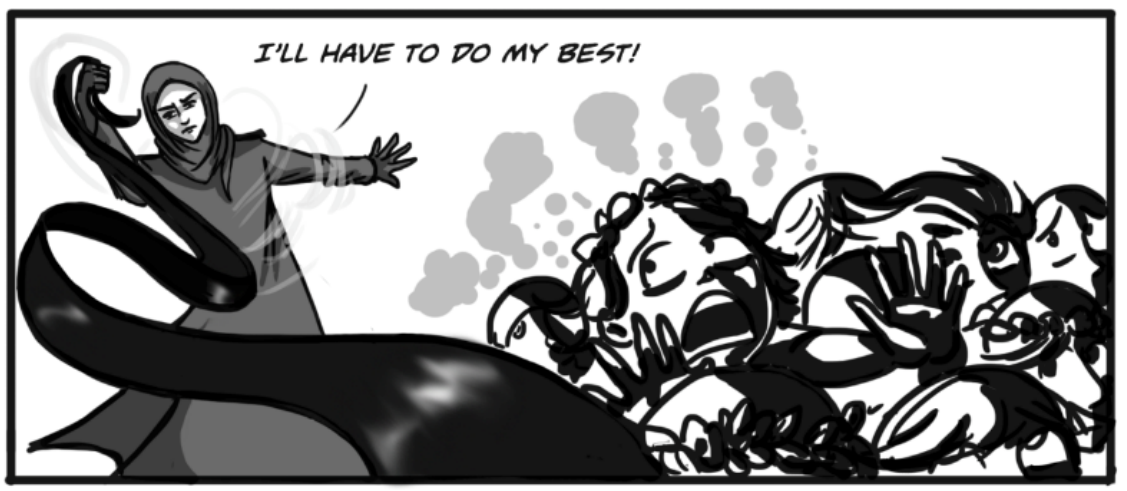

Figure 5. Mohammed, D. (2013). Qahera the Superhero, Egypt, Tumblr, July 20th 2013. C D. Mohammed.

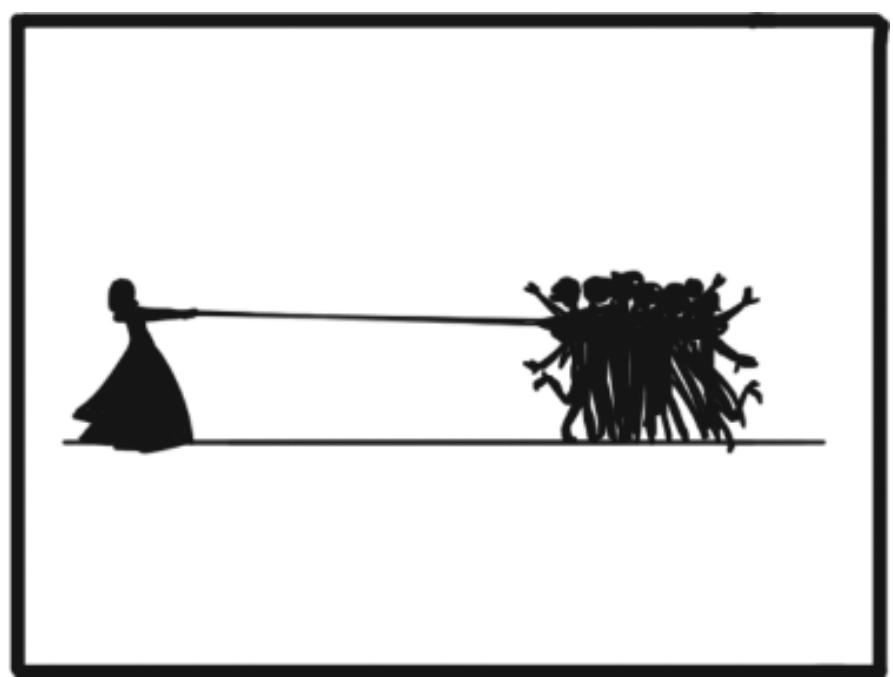

Figure 6. Mohammed, D. (2013). Qahera the Superhero, Egypt, Tumblr, July 20th 2013. C D. Mohammed. 
In Women and Gender in Islam, Leila Ahmed tackles the arguments of two Arab men during the colonial era Qassim Amin (known as the 'Father of Arab Feminism') and Tal'at Harb, a hardline Islamist, arguing that Amin's perspectives are a reinscription of colonial discourses about Islam's inferiority and the 'backwardness' of the veil. His proposals, which included a ban on veiling and segregation, was later espoused by the middle classes and Arab feminists. When coupled with other male thinkers of his time who held his same contempt for the veil, Ahmed concluded that their 'true motivation' was in fact that:

(...) they are men of the classes assimilating to European ways and smarting under the humiliation of being described as uncivilized because 'their' women are veiled, and they are determined to eradicate the practice. (Ahmed, 1993: 165)

Ahmed illustrates how Harb asserted patriarchy like Cromer and Amin, but this time through a reversal. On the debates between both Amin and Harb, she stated that:

(...) the argument between Harb and Amin centered not on feminism versus antifeminism but on Western versus indigenous ways. For neither side was male dominance ever in question. (Ahmed, 1993: 163)

This trope is concretely applicable to Qahera in the 'Part 7: On women's choices' comic which starts off with Qahera and her unveiled friend walking into a restaurant where two men begin to discuss them. One of them terms the veil as 'a shame to see' and surmises that it is oppressive (Mohammed, 2015), arguing that a progressive society would not have so many veiled women and advocates policies that support de-veiling. The other man begins to defend the veil and connects it quickly to 'protection' and states a much-repeated folk analogy about the veil being like candy wrapper. Qahera notices that her friend looks uncomfortable and she disrupts both men, slamming her fists on the table. She begins to yell at them that women are human beings and that 'women's lives are not for you to prove a point' before she storms off (Mohammed, 2015). Interestingly, this comic does not show her using any of her superpowers thus reframing her as an ordinary human being to possibly drive the point home that ordinary feminists can take such action.

The subtleties and nuance of the comic can also be described through other choices on Mohammed's part for drawing a Muslim superhero in bijab. Making it clear that the comic is specifically about commentary on Egyptian life and politics, she states to Disorient:

First, I just thought it would be interesting to have a superhero that doesn't look like the other ones. Second, I like things that represent reality and I wanted her to look like most Egyptian women, to represent them... Also, from a character design perspective it's just nice to draw someone that looks different to stereotypical designs of female superheroes. I would think about how she would fly and what that would look like. And in Egypt a veil [is] such a practical costume. You can just pull up the niqab and you are unrecognized. It's a character that feels both - different and familiar. (Kleer and Taxis, 2019)

We see the practicality of the costume in detail in her comic, 'Part 9: On Things We have to Worry About' where Qahera addresses the everyday lives of Egyptians and the things they need to worry about such as traffic and the economy. A few panels into the comic, we see the character alternating between being veiled and unveiled at times. For instance, in the panel with her addressing a crowd about 'controversial political opinions' she is veiled (Mohammed, 2019). In the panel after that, she is unveiled when speaking to an elderly woman about gender roles. When the costume calls for anonymity such as addressing a crowd on controversial politics, she is veiled. When she is not in the spotlight but addressing someone else's point of view, she chooses to not be veiled. A few panels later, she is seen veiled in a mob fighting back armed men. The veil is seen as practical, it provides anonymity which serves her strategy when fighting off enemies, so they have a harder time identifying her.

In contrast to the western representation of Dust, this type of comic and character is ground-breaking. When the veil is represented for practicality, and not for any orientalist uses the image is not exploitative. Mohammed's superhero is made for an Egyptian audience while American superhero comics are made for western audiences but of course Muslims, people of colour, and marginalised groups form part of western audiences too. Mohammed's work does cater to an Egyptian audience, but she makes it clear that while she primarily draws for the audience, she also draws for western ones as well. She cited the FEMEN comic as an example and admits that she did not translate it in Arabic because of its lack of relevance to Egyptians (Kleer and Taxis, 2019). This recalls Leah Misemer (2017), who discusses webcomics as a space for community-building and solidarity. Misemer points out that webcomics often address multiple audiences, making them a space that serves multiple purposes (Misemer, 2017: 5). By addressing a non-Muslim western audience, Qabera is not only a counter-narrative to popular 
misconceptions of the veil and Muslim women's representation but also potentially a learning space for them. For Muslim audiences in the west, it can function more as a space for solidarity. And for Egyptian audiences, it can function as a space for both familiarity and solidarity for specific political themes such as the refugee crisis in 2015.

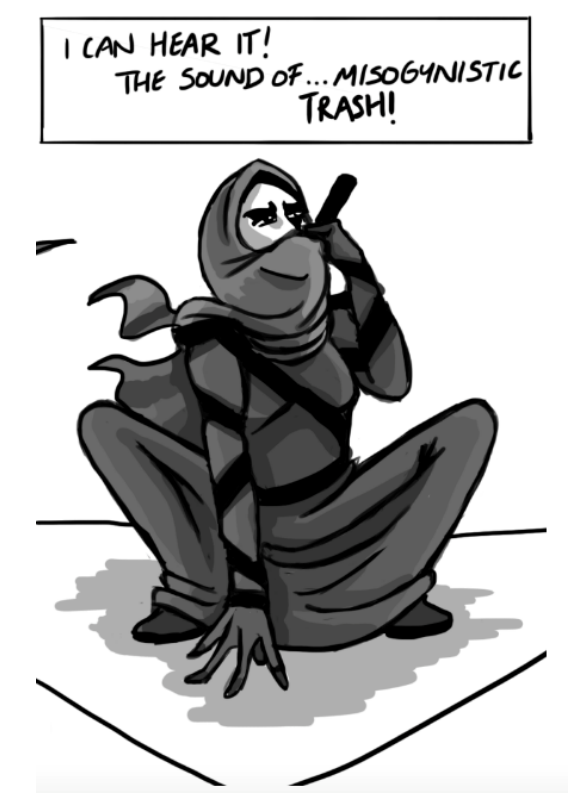

Figure 7. Mohammed, D. (2013). Qahera the Superhero, Egypt, Tumblr, June 30th , 2013. C) D. Mohammed.

While Dust is veiled, she is still sexualised with the form-fitting abaya and niqab with coquettish and startled eyes when viewed up close. Mohammed's character on the other hand is not sexualised and not subject to the male gaze. Panels of the superheroine's eyes betray expressions of anger and frustration when she hears for example the misogynistic cleric. When one considers the cover of New X-Men \#133 where Dust's alluring green eyes and startled expression stares back at the reader, one can't help but think that they were drawn to accentuate her 'exoticism' as opposed to reveal anything substantial about the inner character. With that said, perhaps the one groundbreaking aspect of Dust lies in the fact that she was the first Muslim superhero in the post-9/11 era and it is possible that her representation as a Muslim superhero inspired the later Muslim superheroes in comics such as Kamala Khan, and the characters in The 99. From that aspect, her representation was necessary in its own way.

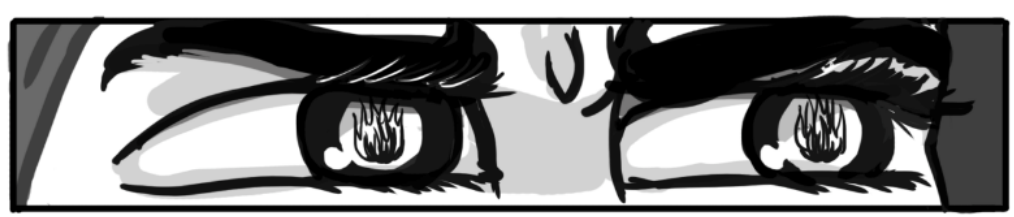

Figure 8. Mohammed, D. (2013). Qahera the Superhero, Egypt, Tumblr, July 20th, 2013. C D. Mohammed.

Keeping these perspectives in mind, Qahera is representative of Spivak's 'absolutely Other' as opposed to the 'domesticated Other'. And in this construction, we see a revolutionary tactic in Qahera as representing the resistance of the 'imperialist self rather than a consolidation of it. The 'absolutely Other' can therefore be deduced as a holistic representation of the Other not refracted through the 'imperialist self and therefore can be best described as a decolonised representation of a veiled Muslim superhero. Technically the 'radical Otherness' in Qahera is instead a radical resistance to colonial biases told through veiling and intersectional feminism.

\section{CONCLUSION}

The growing popularity of webcomics is a testament to the eagerness of members of marginalised groups to speak with their own voices and under their own terms. Whether most creators intend it or not, their work can be a resistance to popular misconceptions and biases found in mainstream publications and their representations of marginalised groups. Mohammed has made it clear that she is intentionally political in her outlooks on class and misogyny, which is apparent through reading her comic. Ironically, while Islamophobia is not an existential threat to her, she does admit that her first encounter with it was through the comments about Qabera in a BBC online article (Kleer and Taxis, 2019). But as a well-informed and passionate creator taking on such political issues, she 
was aware of the growing threat of Islamophobia and has sought to challenge stereotypes of Muslim women through her drawing of Qahera. With comic characters such as Dust still a reality in superhero comics and a lot of marginalised issues being funneled into autobiographical comics, she has made an effective choice in creating a webcomic about a Muslim superhero. By creating a veiled Muslim superhero, she adds a rich and challenging dimension in this increasingly popular archetype.

\section{REFERENCES}

About Us - FEMEN. (n.d.). Retrieved from https://femen.org/about-us/ (Accessed 28 December 2019).

Abu-Lughod, L. (2002). Do Muslim women really need saving? Anthropological reflections on cultural relativism and its others. American Anthropologist, 104(3), 783-790.

Ahmed, L. (1993). Women and Gender in Islam: Historical roots of a modern debate. New Haven: Yale University Press.

Aleya, S. (2018). Interview - Deena Mohammed. Available at: http://www.tarshi.net/inplainspeak/interviewdeena-mohamed-qahera/ (Accessed 28 December 2019).

Bennett-Smith, M. (2013). Topless FEMEN activists protest In Swedish mosque, allegedly called 'whores from hell' (NSFW, video). Available at: https://www.huffingtonpost.ca/2013/07/01/femen-protest-mosquesweden-whores_n_3530171.html (Accessed 3 August 2019).

Davis, J. and Westerfelhaus, R. (2013). Finding a place for a Muslimah heroine in the post-9/11 Marvel Universe: New X-Men's Dust. Feminist Media Studies, 13(5), 800-809.

Duncan, J. (2015, April). Beyond the veil: Graphic representation of Islamic women. The Compass, 1(2), 1-9.

Top 100 Graphic Novels: October 2014. (2014, October). Available at: https:/ /www.diamondcomics.com/Home/1/1/3/237?articleID=156090 (Accessed 3 August 2019).

Edwin, S. (2012, December). Islam's Trojan horse: Battling perceptions of Muslim women in The 99. Journal of Graphic Novels and Comics, 3(2), 171-1999.

Gibbons, S. (2017). 'I don't exactly have quiet, pretty powers': Flexibility and alterity in Ms. Marvel. Journal of Graphic Novels and Comics, 8(5), 450-463.

Kent, M. (2015). Unveiling marvels: Ms. Marvel and the reception of the new Muslim superheroine. Feminist Media Studies, 15(3), 522-538.

Khoja-Moolji, S. and Niccolini, A.D. (2015). Comics as public pedagogy: Reading Muslim masculinities through Muslim femininities in Ms. Marvel. Girlhood Studies, 8(3), 23-39.

Kleer, L. and Taxis, C. (2019). 'You can't be a feminist if you are oppressing other women' - an interview with Egyptian artist Deena Mohamed. Available at: https://www.disorient.de/blog/you-cant-be-feminist-if-you-are-oppressingother-women-interview-egyptian-artist-deena-mohamed?fbclid=IwAR38JbXMIKqZkSDCJzdhgwZyM2iGq URXrGCapU8mdNCPdAoVHNpTIrg17dU (Accessed 3 August 2019).

Lewis, R. (2005). Rethinking Orientalism: Women, travel and the Ottoman harem. London: I.B. Tauris.

McCurry, S. (1985, June). Afghan girl. National Geographic.

McCloud, S. (1994). Understanding Comics: The invisible art. New York: Harper Perennial.

Misemer, L. Webcomics building communities: Depression and visibility in Hyperbole and a half. Comics and Medicine Conference, Seattle, WA, June 2017.

Mohammed, D. (2013, June 30). Part 1: Brainstorm. Available at: https://qaherathesuperhero.com/post/ 64031330049 (Accessed April 25th, 2019).

Mohammed, D. (2015, July 28). Part 7: On women's choices. Available at: https:/ / qaherathesuperhero.com/post/ 125314061196 (Accessed April 25th, 2019).

Mohammed, D. (2019, April 10). On basic equality and such. Available at: https:/ / qaherathesuperhero.com/post/ 184095849551 (Accessed April 25th, 2019).

Mohammed, D. (2019, February 18). Part 9: Things we have to worry about. Available at: https://qaherathesuperhero.com/post/182896728481 (Accessed April 25th, 2019).

Morrison, G., Van Sciver, E. and Rapmund, N. (2002). New X-Men: Issue \#133 [Comic] (Vol. 1). New York, NY: Marvel.

Naghibi, N. and O'Malley, A. (2005). Estranging the familiar: 'East' and 'West' in Satrapi's Persepolis. English Studies in Canada, 31(2-3), 223-247.

Ross, A. (2016). One less woman in politics: Wonder Woman loses job as UN ambassador. The Guardian. Available at: https://www.theguardian.com/world/2016/dec/12/wonder-woman-un-ambassador-gender-equality (Accessed 3 August 2019).

Said, E. W. (1979). Orientalism. New York: Vintage Books.

Satrapi, M. (2004). Persepolis. New York City, NY: Pantheon.

Shaheen, J. G. (1994). Arab images in American comic books. Journal of Popular Culture, 28(1), 123-133.

Shaheen, J. (1991). The comic book Arab. The Link, 24(5), 1-11. 
Spivak, G. C. (1985). Three women's texts and a critique of imperialism. Critical Inquiry, 12(1), $243-261$.

Weir, C., de Felippis, N. and Henry, C. (2005). New X-Men: Hellions (Vol. 1). New York City, NY: Marvel Worldwide Inc.

Whitlock, G. (2007). Soft Weapons: Autobiography in transit. Chicago: University of Chicago Press.

Citation: Hosein, S. (2020). Veiling the Superhero: A Comparative Analysis of Dust and Qahera. Feminist Encounters: A Journal of Critical Studies in Culture and Politics, 4(1), 09. https:/ / doi.org/10.20897/femenc/7913

Copyright (C) 2020 by Author/s and Licensed by Lectito BV, Netherlands. This is an open access article distributed under the Creative Commons Attribution License which permits unrestricted use, distribution, and reproduction in any medium, provided the original work is properly cited. 